\title{
Development of professional metacompetence of teachers in the process of mastering cloud technologies
}

\author{
Tatiana Nadolinskaya $^{1 *}$, Svetlana Rossinskaya ${ }^{2}$, Maria Dyadchenko ${ }^{1}$, Yulia Trofimenko ${ }^{3}$, \\ and Viktoriya Anokhina ${ }^{4}$ \\ ${ }^{1}$ Rostov State University of Economics (RINH), Department of Music Education, Rostov-on-Don, \\ Russia \\ ${ }^{2}$ Rostov Institute of Training and Retraining of Educators, Department of Mathematics and Natural \\ Disciplines, Rostov-on-Don, Russia \\ ${ }^{3}$ Rostov State University of Economics (RINH), Department of Mathematics, Rostov-on-Don, Russia \\ ${ }^{4}$ Rostov State University of Economics (RINH), Department of Russian Language, Culture and \\ Speech Correction, Rostov-on-Don, Russia
}

\begin{abstract}
Literature review of works by Russian and foreign scientists has been performed aiming at reveling essential properties of professional competence of teachers as the competence of the highest level. Course training program has been described, which is comprised of three modules covering urgent issues and technologies of media education, monitoring of quality assessment and efficiency of mastering program, various examples of electronic education products, publications, electronic resources and thesaurus of key notions. The results of the performed studies have been the disclosing of the notion essence of professional metacompetence of teacher, which is expressed in readiness to solve professional tasks under the conditions of mediatization of education system. On the basis of the experimental results, the efficiency of software and methodological support of development of professional metacompetence of teachers has been proved and reflected in diagrams. Therefore, it has been concluded that the development of professional metacompetence of teachers allows to apply interactive forms of education in various online learning environments and provides professional training of teachers of higher quality aiming at independent solution to education problems in the changing educational environment. Recommendations have been given for application of cloud technologies for activation of teacher's activity in monitoring and estimation at various levels of education.
\end{abstract}

Keywords: program, testing, project, electronic education products, lesson.

${ }^{*}$ Corresponding author: tatu60@mail.ru 


\section{Introduction}

Formation of professional metacompetence of teachers is related with mastering media tools and cloud technologies. This is reflected in publications devoted to main trends of development of media education [1]; formation of skills of development of electronic educational resources in additional professional training [2]; development of ICT competence of future teachers using cloud technologies [3]; cloud technologies and system of virtualization under conditions of education modernization [4]; training mathematics using cloud technologies [5].

The studies of foreign scientists devoted to the influence of cloud technologies on education quality [6], cloud-oriented education technologies aimed at organization of research and development activities [7], efficiency of trainings as a tool of development of competences and metacompetences in content context [8] are characterized by theoretical and practical significance. Peculiar interest is attracted to the usage of cloud computations in EPPAIK programs for training of Greece teachers [9].

Contrary to foreign studies, Russian researchers pay insufficient attention to the development of professional metacompetence of teachers in additional professional training. There are few studies of metasubject competence of teacher during additional professional training; however, cloud technologies are not included in the program of teacher's training [10].

The research objective is to substantiate theoretically, to develop and to verify software and methodological support for development of professional metacompetence of teachers using cloud technologies during additional professional training.

The research hypothesis is based on the assumption that the development of professional metacompetence of teachers upon mastering cloud technologies can be successful, provided that:

- the essence and structural components of professional metacompetence of teachers are defined, which are formed stepwise during course training;

- software and methodological support of development of professional metacompetence of teachers is developed and verified in the context of media education.

The research tasks are as follows:

1.To clarify the essence and to determine structural components of professional metacompetence of teachers, formed stepwise using module training technology.

2. To prove the efficiency of software and methodological support for development of professional metacompetence of teachers using cloud technologies.

3. To analyze the experimental results in terms of highlighted criteria and indices of efficiency of development of professional metacompetence of teachers.

\section{Methods}

The formulated problems were solved using a set of theoretical and experimental methods: analysis and systematization of scientific publications; pedagogic experiment; modified Rokeach's method (value-motivational component of professional metacompetence); Luchins's method (cognitive component); statistical processing by Student's t-test (activity component).

\section{Results}

Professional metacompetence of teacher is a competence of the highest level. Professional metacompetence of teacher is comprised of value-motivational, cognitive, and activity and 
structural components. Each component is correlated with certain criterion and indices, a set of diagnostic procedures, allowing to reveal levels of development of professional metacompetence of teachers by means of monitoring [11].

Aiming at efficient development of professional metacompetence of teachers, the program has been developed using cloud technologies based on module education [12].

The program objective is the development of professional metacompetence of teachers by mastering cloud technologies under conditions of information educational environment.

The program is comprised of three modules:

Module 1: Urgent issues of media education at current step: it helps to study basic categories of integrated media education related with studying interactive forms of teacher work, to learn the differences between cloud technologies and cloud services, to study the types of clouds, to compare variants of electronic educational resources. The first module is completed with test assignments allowing to determine the knowledge level of key categories of media education (https://forms.gle/zTe8r7iLSYMNZC6Y8).

Module 2: Modernization of content of school programs on the basis of cloud technologies and electronic resources stipulates studying technologies for organization of network research activity, updating content of school programs using GlobalLab online environment and resources of Russian digital education platform LECTA. The module is completed with test assignments allowing to determine the level of readiness of teachers for development and simulation of electronic educational resources (https://forms.gle/qCJSz3iUZKz9KCSCA ).

Module 3: Development and simulation of electronic educational resources by means of cloud technologies discloses the features of electronic education in school; provides methodological recommendations for working in RES electronic educational environment, development of toolkit of electronic lesson in Web application; it contains scenarios of interactive lessons for various subjects. Description of network project development on the basis of computer communications has practical significance. Test assignments allow to determine the level of formation of teacher's media skills (https://forms.gle/qkyaXZhNkFrXb9UQ8).

\section{Discussion}

The pedagogical experiment was carried out with 100 respondents from Rostov oblast in 2019-2020 academic year. The teachers (natural and humanitarian cycles) were subdivided into reference (RG1, RG2) and experimental (EG1, EG2) groups, each by 25 persons.

In order to determine the level of formation of value-motivational component of professional metacompetence in reference and experimental groups at ascertaining and final stages of the experiment, the Rokeach's method was used [13]. It was modified into valuestargets (terminal values) and values-tools (instrumental values):

- the terminal values, providing opportunity of continuous development in the field of media (advanced training, participation in webinars, master classes, etc.), network interaction and development of EEP in cloud services;

- the instrumental values, determining readiness of teachers to apply key notions of media education, use cloud technologies in their professional activity; skills to apply interactive forms of work with students.

While interpreting the obtained results, it was taken into account that the value rank was inversely proportional to its significance, thus, the value with the rank 1 was more significant, the least significant was that with the rank 21 [14]. At the ascertaining stage, it was revealed that the values required for a teacher for development of professional metacompetence were characterized by high ranks, i.e., low level of significance. At the final stage, it was revealed 
that the mentioned values were characterized by low ranks, hence, the high level of significance (see Fig. 1, 2).

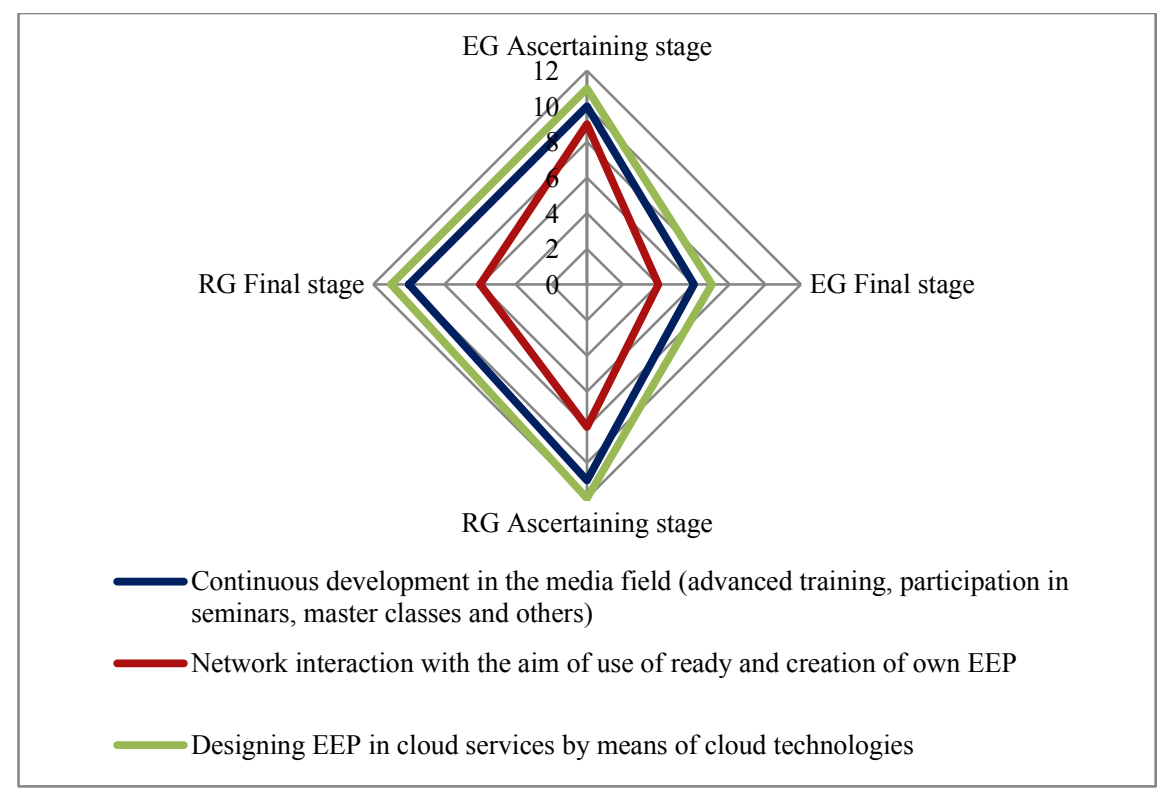

Fig. 1. Estimation of average terminal values of teachers at ascertaining and final stages of experiment.

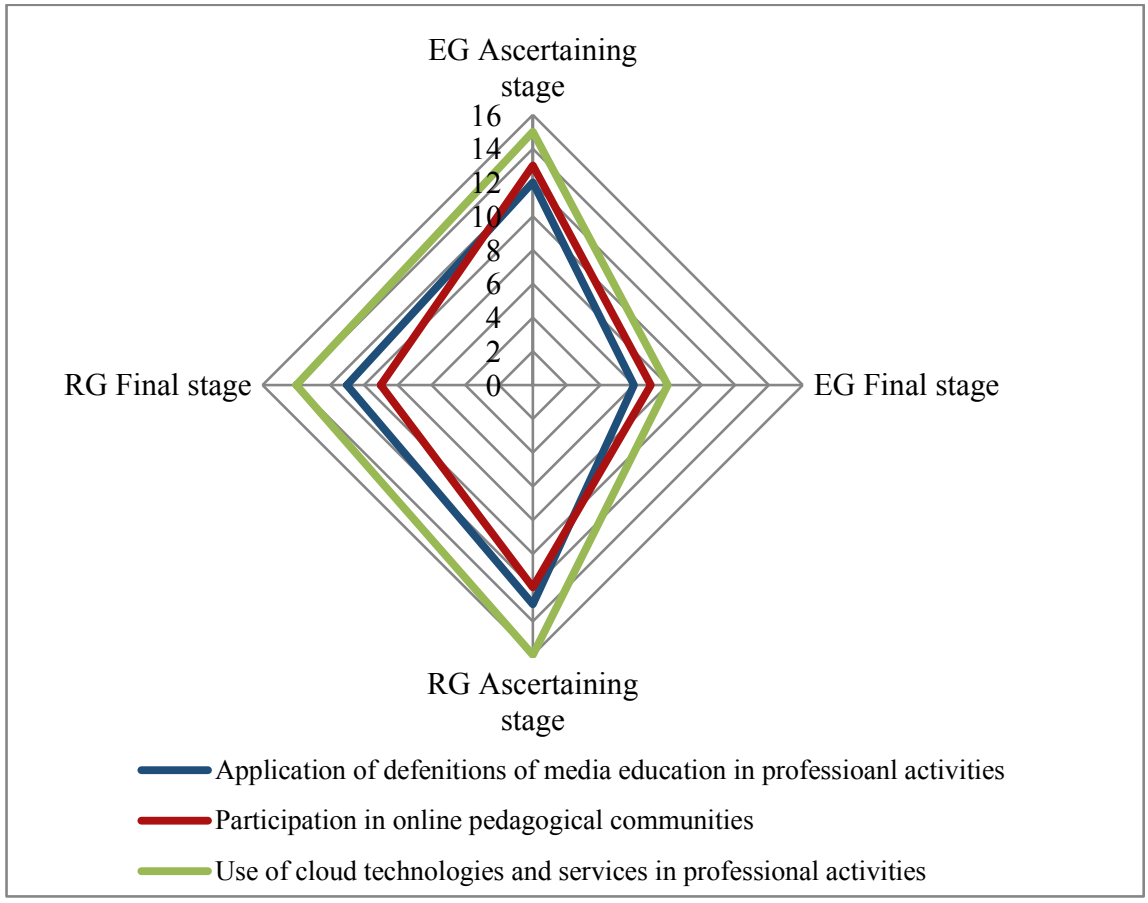

Fig. 2. Estimation of average instrumental values of teachers at ascertaining and final stages of experiment. 
The level of formation of cognitive component of professional metacompetence was determined according to the method by A. S. Luchins: Flexibility of thinking [15]. The obtained data were processed using the coefficient of creative flexibility $\left(K_{\text {flex }}\right): K_{\text {flex }}=\frac{M_{a v}}{M_{1}}$

Herewith, $K_{\text {flex }}$ from 0.5 to 1 evidenced flexibility and creativeness of thinking, lower than 0.5 - no $K_{\text {flex }}$. Comparison of results at ascertaining and final stage in reference and experimental groups demonstrated that the reference groups were characterized by lower level of creative flexibility of students. In experimental groups, the students more rapidly transited from one type of professional activity to another, i.e., they had more plastic thinking (see Fig. 3).

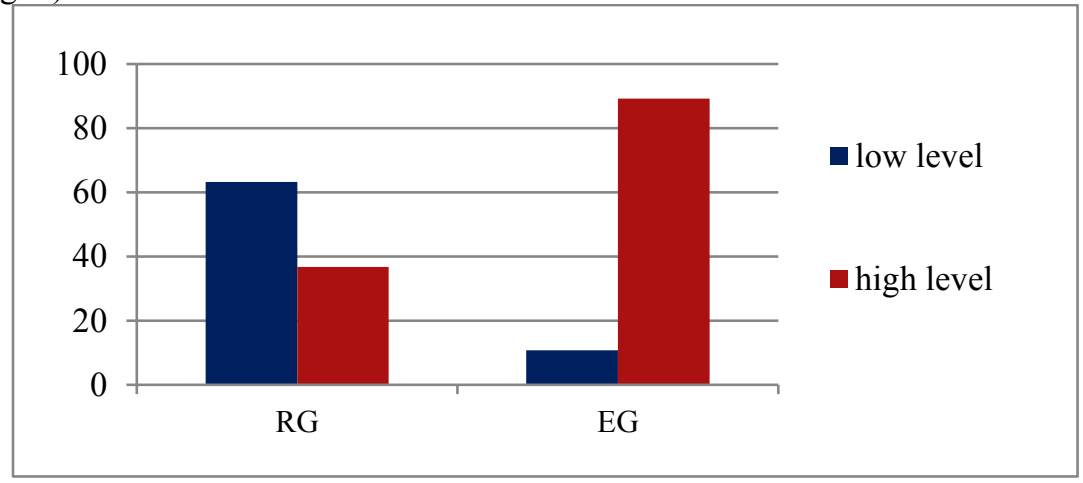

Fig. 3. Ratio of coefficient of creative flexibility of teachers.

At final research stage, the level of formation of activity component of professional metacompetence of teachers was determined by the test by E. P. Ilyin: Creative abilities [15]. The data obtained at the start and at the end of the experiment were interpreted according to the levels of development of professional metacompetence (70-100 scores: creative level, 4970 scores: heuristic level, 0-40 scores: reproductive level). The experimental results of creative abilities of teachers demonstrated domination of heuristic and creative level of development of professional metacompetence for the trainees in groups EG1 and EG2 in comparison with the groups RG1 and RG2 (Fig. 4).

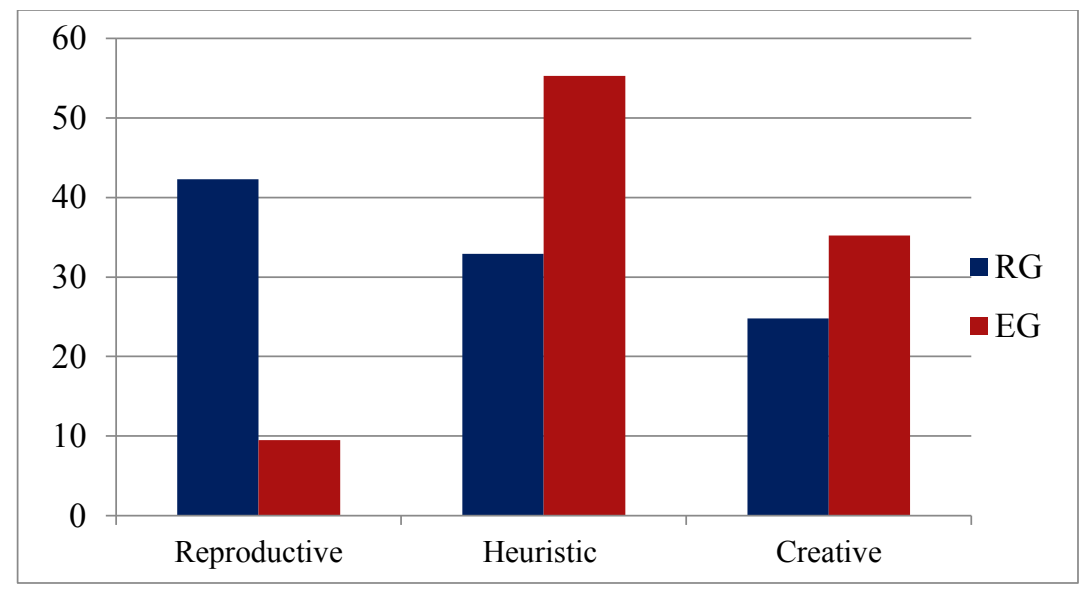

Fig. 4. Ratio of coefficient of development of professional metacompetence.

After completion of Module 3 the efficiency of development of activity component of professional metacompetence was determined by test assignments. The Student's t-test, 
characterizing the degree of significance of differences during execution of test assignments in reference and experimental groups, was determined on the basis of a set of calculations:

1. average arithmetic of the results was calculated;

2. deviation of single indices from average arithmetic was calculated;

3. dispersion was determined;

4.average arithmetic values at the start and at the end of the experiment were compared;

5.the confidence level of executing assignments in reference and experimental groups was determined [16].

Mathematical processing of the experimental data demonstrated that the reference value of Student's t-test for 5\% level at 28 degrees of freedom was 8.048. Statistically substantiated conclusion could be made that, while comparing two average arithmetic values M1 (18.5) and M2 (31.7) at the start and at the end of the module studying, there was significant difference between the results of assignment execution. If at the start of training the teachers demonstrated approximately the same level of formation of media skills, then at the end of the course training, the experimental groups showed positive trends of formation of media skills, which were applied in interactive forms of work (development of electronic lessons, research projects, etc.).

\section{Conclusion}

The experimental results have confirmed the validity of the hypothesis and efficiency of cloud technologies for additional professional training. The assumption that development of professional metacompetence of teachers requires for special software and methodological support has provided positive results. Statistic processing of the obtained data has proved that cloud technologies are efficient tool to develop professional metacompetence by teachers, assisting to master interactive forms of work with students of various ages. New opportunities appear for implementation of monitoring and estimation by teachers at various levels of general and additional professional education, for studying pedagogical conditions of EEP development in various online environments.

\section{References}

1. A.V. Fedorov, A.A. Novikova, Mediaobrazovaniye v Vedushchikh Stranakh Zapada [Media Education in the Leading Western Countries] (Informatsiya Dlya Vsekh, Moscow, 2014)

2. S.R. Khabliyeva, Z.K. Kargiyeva, Nauchnoye obespecheniye sistemy povysheniya kvalifikatsii kadrov, 1(42), 34-42 (2020)

3. V.G. Shevchenko, Informatics and Education, 8, 55-57 (2016)

4. M.V. Shevchuk, Bulletin of the Moscow Region State University. Series: Pedagogics, 2, 244-250 (2017)

5. G.A. Aleksanyan, Formirovaniye Samostoyatelnoy Deyatelnosti Studentov SPO v Obuchenii Matematike s Ispolzovaniyem Oblachnykh Tekhnologiy [Formation of independent activity of students of secondary vocational education institutions using cloud technologies] (Northern (Arctic) Federal University named after M.V. Lomonosov, Yelets, 2014)

6. K. Yadav, International Journal of Innovative Research in Computer and Communication Engineering, 2(2), 3108-3112 (2014)

7. D.M. Bodnenko, Information Technologies and Learning Tools, 48(4), 122-139 (2015) 
8. C. Bach, R. Suliková, Management, 14(4), 289-304 (1019). https://doi.org/10.26493/1854-4231.14.289-304

9. V. Kasiolas, The use of cloud computing technologies in teachers' education and training (2017). Accessed on: September 20, 2020. [Online]. Available: https://www.academia.edu/41973224/

10. O.N. Bogdanova, Stanovleniye metapredmetnoy kompetentnosti uchitelya v protsesse dopolni-tel'nogo professional'nogo obrazovaniya [The Establishment of a Teacher's Interdisciplinary Competency in the Process of Additional Professional Education], Thesis (Krasnoyarsk State Pedagogical University named after V. P. Astafyev, Krasnoyarsk, 2018)

11. T.V. Nadolinskaya, S.A. Rossinskaya, Modern problems of science and education, 2 , (2020)

12. T.V. Nadolinskaya, S.A. Rossinskaya, Konstruirovaniye i modelirovaniye elektronnykh obrazovatel'nykh s ispol'zovaniyem oblachnykh tekhnologiy [Design and modeling of electronic educational products using cloud technologies] (Rostov Institute for Advanced Studies and Professional Retraining of Educators, Rostov-onDon, 2019)

13. N.F. Greben (Ed.), Psikhologicheskiye testy dlya professionalov [Psychological tests for professionals] (Sovremennaya shkola, Minsk, 2007)

14. S.V. Petrova, Formirovaniye mediakompetentnosti pedagogov gumanitarnokhudozhestvennykh distsiplin v sisteme dopolnitel'nogo professionalno-go obrazovaniya [Formation of media competence of teachers of humanitarian and artistic disciplines in the system of additional professional education], Thesis (Rostov State University of Economics, Rostov-on-Don, 2018)

15. Ye.P. Ilyin, Psikhologiya tvorchestva, kreativnosti, odarennosti [Psychology of creativity, creativity, giftedness] (Saint Petersburg, Piter, 2009)

16. G.F. Lakin, Biometria [Biometrics] (Vysshaya shkola, Moscow, 1980)

17. A.V. Khutorskoy, Metapredmetnyy podkhod v obuchenii: nauchno-metodicheskoye posobiye [Metasubject approach in teaching: scientific and methodological manual] (Eidos; Institute of Human Education, Moscow, 2012)

18. V.A. Shershneva, Bulletin of the Krasnoyarsk State Pedagogical University named after V.P. Astafiev, 1(51), 80-89 (2020)

19. Zh.T. Ualiyeva, D. Sabituly, R. Bostek, Bulletin of the Kazakh Academy of Transport and Communications named after M. Tynyshpaeva, 3, 288-295 (2014) 